\title{
How COVID-19 Has Exacerbated Inequality in Higher Education in Brazil
}

\author{
Francisco Ricardo Miranda Pinto \\ Centro Universitário UNINTA \\ ricardomiranda195@gmail.com
}

\begin{abstract}
Drawing on educational census data and a review of news articles and higher education policies in Brazil, this article examines the impact of COVID-19 on the access and retention of the low-income Brazilian population in higher education. Guided by the question, "What is the impact of COVID19 on the most vulnerable population in Brazil in terms of access to, and retention in higher education?", the paper is structured in two sections: the first offers a short historical overview of Brazilian higher education; the second examines the impact of the pandemic on student retention in higher education, looking at factors such as social isolation, job and income precarity, use of Information and Communication Technologies (ICT), internet access, and technological resources. I argue that distance education offered by private higher education institutions benefits the privileged students and that the effects of the pandemic are detrimental to the socially disadvantaged students since those who are in public universities do not always have access to technology, and those who study in private universities feel the impact of not being able to pay tuition fees, besides the loss of several jobs in different sectors. In conclusion, I recommend policy initiatives to improve access to higher education.
\end{abstract}

\section{Introduction}

Following the Covid-19 outbreak in March 2020 and a social isolation mandate in Brazil, the Ministry of Education, by Decree No. 343/2020 (Federative Republic of Brazil, 2020b), suspended classes in the education system, and authorized the use of Information and Communication Technologies (ICT) to continue the academic year, in line with policies adopted in other large nations such as China (Zhu \& Liu, 2020; Daniel, 2020). 182,600 institutions suspended onsite attendance, leaving 47 million Brazilian students in primary, secondary, and tertiary education without classes. Like 850 million students in 191 countries around the world, they had to adapt to a new reality of remote or no classes at all (Mustafa, 2020). This paper considers the impact of COVID-19 on the access and retention of students in higher education, especially among lowincome groups, guided by the question, "What is the impact of COVID-19 on access to and retention in higher education among socially vulnerable students in Brazil?" I provide a brief historical overview of public policies in Brazil designed to ensure access to higher education as well as their limitations. Against the background of an already unequal and volatile higher education system, I examine the challenges faced by socially disadvantaged students in higher education due to the socioeconomic and institutional effects of the COVID-19 pandemic. I argue that the pandemic and its impacts results in increased dropout, reduced access, and consequently greater exclusion of students from higher education.

The study draws on data from government sources and legislative documents, as well as on literature from civil society institutions, census data, and journalistic articles about the pandemic in major national newspapers, news magazines, and websites such as UOL, Estadão, Agência Brasil, 
and Veja. The paper is structured in two sections: the first offers a historical overview of Brazilian higher education; the second examines the impact of the pandemic on student retention in higher education, looking at factors such as social isolation, job and income precarity, use of Information and Communication Technologies (ICT), internet access, and technological resources. In conclusion, I recommend policy initiatives to improve access to higher education.

\section{A Short History of Higher Education in Brazil}

The history of higher education in Brazil can be traced back to the arrival, during the Peninsular War, of the Portuguese royal family in the colony in 1808, and the subsequent growth of a bourgeois class. During the nineteenth century, eleven universities were founded, starting with the School of Surgery and Anatomy in Bahia (DeHumerez \& Jankevicius, 2015). At that time, higher education was conceived as preparation for professional practice, and was reserved for the white bourgeois elite, resulting in the denial of access to higher education, and thereby of social mobility, to the majority of Brazilians over many generations. Despite the absence of census data on higher education until 1950, there are numerous indicators signaling that access was limited to the upper socio-economic classes. Considering the census of the Brazilian Institute of Geography and Statistics, in 1950 the number of enrollments in higher education was 210,270. That figure rose modestly to 593,009 in 1970 (Brazilian Institute of Geography and Statistics, 1950; 1970), continued to grow to 1,377,286 in 1980, and reached the marker of 2,125,958 students in 1998 (Anísio Teixeira National Institute of Studies and Educational Research, 2000a). Despite that increase, only 12\% of the population aged 19-24 years attended university in 1997 (Saviani, 2010). The inequality gap prompted the emergence of several social and intellectual movements in the first half of the twentieth century, demanding more egalitarian access to quality education.

As a result of pressure from civil society, a series of laws, collectively known as the National Education Guidelines and Bases Law (LDBEN), was passed. The first of those, Law No. $9394 / 1996$, forced the federal education system to universalize primary and secondary education and signaled the need for higher education to follow the same path, since a far larger number of young people would be graduating from high school (Federative Republic of Brazil, 2017a). Thus, Law No. 9394/1996 may be considered the starting point for all public policies aimed at extending access to Higher Education in Brazil; it reformed its structure and organization, opened up the possibility of private higher education institutions (HEIs), and of distance continuing education for professionals. After Law No. 9394/1996, there was a slight increase in the number of enrollments, going from 1,868,529 that year to 2,694,245 in 2000, almost reaching the projected target for 2004 . Those figures represent an increase of $20.6 \%$ in the period from 1980 to $1994,28 \%$ from 1994 to 1998, and 42.6\% from 1994 to 1999. By 2010, the law had started to show positive results, as the percentage of the population enrolled in higher education reached $6,379,299$, rising to $8,450,755$ in 2018 (Anísio Teixeira National Institute of Studies and Educational Research, 2000a; 2000b; 2001; 2012 ; 2019). However, that legislative framework was limited by a failure to address factors such as social vulnerability, geographic access, systemic racial or ethnic exclusion, socioeconomic status, and poor quality in the provision of public primary and secondary education.

President Fernando Henrique Cardoso initiated several public policies aimed at extending access to higher education to socially vulnerable populations with the creation of the National High School Examination (ENEM) in 1998, and the Higher Education Finance Fund (FIES) in 1999. The latter greatly expanded the Educational Credit Program (CREDUC) launched by the military dictatorship of Ernesto Geisel in 1975 (National Education Development Fund, 2017). From 2003, the government of President Luís Inácio Lula da Silva embarked on a series of education policies 
designed to democratize access to higher education. Significantly, those aligned the standard curriculum for secondary education with ENEM, and replaced the traditional and non inclusive "vestibular entrance examinations". The new HEI entrance system did not, however, immediately result in increased admission to either public or private HEIs. In the latter case, access was limited by high monthly tuition fees. Thus, even though public institutions lacked the capacity to admit the many students who were now graduating from high school, the private network was underused.

Due to the disparity in the quality of teaching between public and private secondary schools, ENEM was not a guarantee of access to and student retention in higher education. To address the situation, the University for All Program (ProUni) was created in 2004, offering scholarships of up to 100\% to private HEIs (Ministry of Education of Brazil, 2018a). FIES was also expanded, opening greater access to socially vulnerable young people, and also covering up to $100 \%$ of tuition costs. Funding through ProUni or FIES was conditional on taking ENEM.

By 2010, the adoption of ENEM by most public HEIs as their admission criterion had greatly increased the number of admissible applicants to higher education (Ministry of Education of Brazil, 2018b). To ensure greater access and standardize the university admission process, the Ministry of Education developed a platform called the Unified Selection System (SISU) (Ministry of Education of Brazil, 2020a). It applied a unified application criterion to all public HEIs, and expanded the guarantee of equal opportunity to the national level. Through SISU, candidates can apply to either a public or a private HEI, by simultaneously applying for funding through ProUni and FIES for the latter kind of institution. Between 2009 and 2017, SISU, FIES and ProUni raised enrollments to public and private HEIs by approximately two million.

However, that advance in enrollments has stalled under the last three presidents of Brazil - Dilma Roussef, Michel Temer and Jair Bolsonaro - due to cuts in the budgets of ProUni and FIES. Between 2010 and 2014, the number of student loans approved rose from 70,000 to 739,000. That number fell by $62 \%$ to 281,000 in 2015 , and even further to 170,095 by 2017 . The number of approved loans rose again to 300,000 in 2018 , but only $24 \%$ of those were granted under the new financing criteria, which were based on family income, and other sources of finance. Although more loans were available, the new criteria made them difficult to access. It is estimated that only 100,000 student loans will be granted in 2020, and that number is expected to drop to just over 50,000 in 2021 . This trend has directly and negatively affected the most vulnerable sections of Brazilian society, who are unable to afford monthly tuition fees for private HEIs (Saldaña, 2019; Brazil247, 2020). Young people voiced their concern and expressed resistance to the cuts made by the Temer government by taking to the streets in 2016 (National Union of Students, 2016).

By considering the establishment of public policies towards the access to Brazilian Higher Education, we may highlight the movement started by the State University of Rio de Janeiro in 2001, which created its own quota system until it was developed into Quota Law No. 12,711/2012 (Federative Republic of Brazil, 2012a), enacted as a reparatory act for the ethnic-racial and socioeconomic inequalities that have prevailed in Brazil since its colonial era, therefore an affirmative action (Feres Junior et al., 2018). The law proposed the reservation of places in the universities of the federal education system with admission through public exams. It initially targeted students who had attended secondary education in public schools, the self-declared blacks, browns, and indigenous people; but excluded the disabled, and graduates from the Youth and Adult Education (EJA) modality. Its Article 2 also stated to consider the students' performance coefficient in the common core subjects [standardized throughout the federation] throughout high school (Federative Republic of Brazil, 2012a), to be eligible for a place. 
Message No. 385/2012 (Federative Republic of Brazil, 2012b) vetoed the aforementioned article by alleging that there exists no standardized evaluation in high school that could justify the use of the performance coefficient as a parameter. The scope of the Quota Law was expanded in Decree No. 7.824/2012 (Federative Republic of Brazil, 2012c) by including the results of the National High School Examination (ENEM) as selection criteria, and also including adult education students. Law No. 13.409/2016 (Federative Republic of Brazil, 2016) and Decree No. 9.034/2017 (Federative Republic of Brazil, 2017b) regulated the consideration of disabled students in the Quota System, following the adoption of the Statute for the Disabled through Law No. 13.146/2015 (Federative Republic of Brazil, 2015), which mandated education systems to accommodate physically disabled students.

Although they represent the majority of the population, black, indigenous, and disabled are considered minority groups previously excluded from universities. The quota sytem is well accepted by some (Badalotti et al., 2019), but also viewed critically due to its meritocratic principles and perpetuation of ethnic-racial tensions (Moura \& Tamboril, 2018). Although at the level of rhetoric it is considered that the public quota for access to higher education has reached its goal, the reality looks different, considering that many young people from minority groups in Brazil do not have access to higher education. It is fair to say that the policy was able to mitigate the inequality in access to higher education, but it has not reached everyone, and the so-called elite programs, namely Medicine, Law and Engineering still fail to include self-declared black, brown, indigenous or disabled students from public schools (Feres Junior et al., 2018). Moreover, recent laws such as Ordinance No. 1122/2020 of the Ministry of Science, Technology, Innovation, and Communications (MCTIC) determine that technology and scientific innovation should be given priority in the allocation of public research funding to HEIs in the four-year period of 2020-2023 to the detriment of other areas such as the humanities and social sciences (Federative Republic of Brazil, 2020c).

Although the National Educational Plan (PNE) projects an annual growth of $1.8 \%$ in HEI enrollments (Ministry of Education of Brazil, 2020b), there are other factors that reinforce the difficulties in access to higher education. The less developed regions of the country do not have a wide distribution of public HEIs, blocking or hindering access for high school graduates unable to move to large urban centers. Only in recent years public HEIs have started opening decentralized campuses in the most remote regions of the country. On the other hand, thanks to Decree No. 9057/2017 (Federative Republic of Brazil, 2017c), which allows for and recognizes degrees obtained entirely through distance education, that sector has expanded rapidly. Distance education has given a significant portion of the Brazilian population living under precarious socioeconomic conditions a new level of access to higher education. In Brazil, distance education has a much lower cost than onsite classes, and the institutions that offer this teaching modality can go beyond urban centers and reach even the most distant regions of the country. However, even with all the possibilities that distance education potentially provides, participation is hampered by insufficient access to laptops and devices with sufficient capacity to attend online classes, lack of technological know-how and considerable resistance to and low acceptance of distance learning within the Brazilian educational institutions.

The historical context shows that public policies alone do not guarantee equitable access to higher education, nor to better jobs or a higher quality of life. The registration data available in the 2018 high school census (basic education stage in Brazil) (Anísio Teixeira National Institute of Studies and Educational Research, 2021a) and enrollment in higher education 2019 (Anísio Teixeira 
National Institute of Studies and Educational Research, 2021b) prove a significant gap between those who get out of high school and enter higher education. However, as the educational census Brazil does not categorize by socioeconomic status, its informative value is limited. It is important to consider the history of the inaccessibility of poor, black and other minority groups to higher education and mishaps experienced by those who manage to enter higher education. Ever since Brazil emerged from its colonial status in the nineteenth century, its education system has been characterized by strict social stratification and elitism. Exclusion and unequal access are supported by discourses that function to segregate and maintain existing power structures. For example, in a 2019 interview, former Brazilian Minister of Education, Ricardo Vélez Rodríguez, rejected the idea of university for all, by stating that access to university should be a "privilege" of a small elite (Gazeta do Povo, 2019).

Even under pre-COVID-19 conditions, the offer of higher education in Brazil was insufficient to meet demand, and access was very difficult for people living in slums or remote regions. The situation was aggravated by the COVID-19 pandemic, which has laid bare the structural barriers to universalization of higher education in Brazil. Those include unequal access to information and communication technologies (ICT), internet access, unemployment, income reduction, and competing responsibilities. The COVID-19 crisis has exacerbated many of Brazil's problems in terms of social inequality, unequal income distribution, and the poor quality of public schools.

\section{The Impact of COVID-19 on Higher Education in Brazil}

The COVID-19 pandemic has profoundly changed the lives and livelihoods of people in Brazil. It has disrupted social relations, routines, and family responsibilities, and led to a reduction in working hours, and the loss of jobs and family income. It has also exposed weaknesses in the Brazilian education system, intensified social vulnerability, and undermined human development by interrupting students' progress at all educational levels in the reality of online education (Araújo et al., 2020; UNESCO-IESALC, 2020).

Instabilities in the labor market directly affect students' interest in attending higher education. In a survey commissioned by the Brazilian Association of Higher Education Administrators (Brazilian Association of Higher Education Administrators, 2020a) out of 1,607 students at private HEIs from all regions of Brazil, $52 \%$ of the participants stated that they hoped to continue their studies after the pandemic, $42 \%$ expressed uncertainty about whether they would continue their studies, $4 \%$ intended to drop out, and $2 \%$ confirmed that they would definitely drop out because of the pandemic. Those data approximate, in part, the results of the study by Aucejo et al. (2020) with 1,500 university students from the United States of America. In that study, among the interviewees, the intention to give up studying due to COVID-19 is almost none, while in Brazil the sum of those intending to give up studying reaches $48 \%$ of those surveyed. Among the young people in Brazil, there are those who confirm they are delaying their studies (13\%), delaying some courses $(11 \%)$ or changing courses (12\%), and $25 \%$ of the participants expected to postpone the entry into undergraduate studies. Between the months of April and May 2020, the non-payment rate of higher education fees rose by $75 \%$, reflecting the crisis experienced by those who bear total or partial cost of their studies together with family responsibilities (Brazilian Association of Higher Education Administrators, 2020a). The threat of job loss was particularly great for minority groups such as self-declared black (pretos), brown (pardos), and indigenous people, and low-income or poor families. It has to be considered that the state bears the other part of students' debts from those who receive half of the amount through FIES or PROUNI. However, the payments under these schemes do not apply to distance education programs. In addition, there are courses that are excluded from public policies 
for student financing or subject to certain conditions, for example, social sciences, teacher training and pedagogy.

The ProUni scheme that offers scholarships for students to study at private HEIs, does not explicitly mention distance education. Although some sites indicate that ProUni student funding grants are available for distance education, in practice, candidates do not find the option when they register. Segenreich (2009) confirms that the possibility of offering ProUni for distance education was considered in 2006; however, in some states there were no institutions available who offered distance education and the available information is confusing and unclear. The website of the Brazilian Ministry of Education still does not offer data distributed by teaching modalities. Of those who pay for their own studies, $22 \%$ stated that they were considering dropping out because of the cost burden, while $60 \%$ mentioned changing labor market conditions as a result of the pandemic, and as a factor influencing their decision whether to continue their studies (Brazilian Association of Higher Education Administrators, 2020b).

Although the finances of HEIs are not part of the analysis in many of the studies aimed at analyzing the impact of COVID-19 on teaching and learning, the existence of non-payment and even the dropout of academics, with the onset of the pandemic, lead Brazilian and international higher education institutions to face difficult budget situations concerning the maintenance of employees and suppliers, that also compromised their post-COVID-19 solutions. Budget losses are expected also in universities in the United States of America, Australia, as well as in the United Kingdom, (Burki, 2020; Ahlburg, 2020), considering that their income relies to a high degree on international students, who are unable to travel due to the restrictions.

Brazil already had about 12.9 million unemployed people before the COVID-19 pandemic. In May 2020, the unemployment rate was $10.5 \%$ with a peak of $14.3 \%$ in August, and a slight slowdown to $13.7 \%$ in September (Brazilian Institute of Geography and Statistics, 2020). The crisis has affected the job of at least one member of $57.2 \%$ of families, the need for social isolation caused impediments to work for $45.5 \%$ of families, and $14.3 \%$ have completely lost their jobs (Getúlio Vargas Foundation, 2020), directly impacting both the income of Brazilians, as well as their family relationships, health, and life quality (Bezerra, Silva, \& Soares, 2020). Studies carried out in the United States of America by Burki (2020) show that more than 20 million Americans lost their jobs in April 2020, the month following the confirmation of the pandemic by the WHO. Son et al. (2020) confirm the impacts of COVID-19 on the finances of participants whose parents lost their jobs. Students participating in the study by Aucejo et al. (2020), point to the loss of their own jobs or internship vacancies, as well as the jobs of their own family members, where the rate reaches $61 \%$ of respondents.

The current situation of income and job instability has led many researchers to rethink the acquisition and maintenance of student loan debt. Examples of the current and future impacts of COVID-19 on market instabilities, and predictions of academics concerning access to and permanence in Higher Education are highlighted in the studies by Son et al. (2020) and Burki (2020). Addressing the risks of non-payment, some private institutions have developed policies to reduce monthly fees during the pandemic period. Parents, students, and guardians have opened up discussions about full charges for remote classes, and in one case, a federation state has legally mandated a 30\% reduction in tuition fees (Law No. 17208/2020; State of Ceará, 2020). Similar attempts have been made in other states, but have been repealed by the federal court. Medical students from a private HEI in the State of São Paulo have filed a lawsuit to deduct tuition fees, but it was revoked by the court. According to the Brazilian Association of Higher Education 
Administrators (2020b), other legal actions but have been rejected by HEIs or are pending. In November 2021, the Superior Court of Justice of Brazil (STF) ruled that discounts on monthly payments by court order during the pandemic are unconstitutional (National Association of private Universities, 2021).

In addition to employment and income issues, $8 \%$ of participants in the Brazilian Association of Higher Education Administrators (2020b) survey have stated that they intend to discontinue their studies because their HEI has not made its programs available through the distance or remote modality. That reflects the fact that many public HEIs do not have the adequate capacity to support the use of ICT, digital platforms, and virtual learning environments in order to keep charging tuition during this crisis. In general, ICT infrastructure is inadequate in many public and private Brazilian HEIs. The Brazilian Association of Distance Education has compiled a kind of dossier with several subjects dealing with distance education and COVID-19. In one of them, Furuno (2020) reflects on the possibility of HEI without online teaching platforms, while Tomazinho (2020) reports the difficulties of HEI with the broadband service offered in Brazil. Notwithstanding Resolution No. 343/2020 (Federative Republic of Brazil, 2020a), which allows for the use of ICT to deliver university curricula remotely, the crisis has revealed that Brazil's public education system, like many others around the world, was quite unprepared for a switch to distance learning modalities (Kerres, 2020; Adnan \& Anwar, 2020).

Private HEIs have been better prepared to move online. Due to Ordinance No. 2117/2019 (Federative Republic of Brazil, 2019), which allows for the provision of up to $40 \%$ of the theoretical course load on digital platforms, the use of ICT for distance learning is already a reality in many private HEIs. That has facilitated the continuity of courses. However, the application of the ordinance is uneven in public HEIs, which reflects resistance to distance education. Barone (2020), who has reported about platforms made available by the Ministry of Education that are not used in higher education, reiterated the resistance to the use of technology in teacher training, and the difficulty in adopting a new way of teaching. The academic year in public universities in 2020 was greatly disrupted as students were affected by social inequalities, geographic remoteness, and access to ICT. The geographic remoteness of many municipalities and the low availability of broadband internet in both urban and rural households has been a major factor limiting the adoption of distance modalities during the pandemic. The 2018 Survey on the Use of Information and Communication Technologies in Brazilian Households, carried out by the statutory Brazilian Internet Steering Committee (2019), after surveying just over 33,000 households, has revealed that internet connection is not yet universalized, and it is worse in rural areas where just $44 \%$ of the households surveyed had access to the internet.

While the majority of the Brazilian population is concentrated in urban zones, Brazil has more than 5,000 municipalities mostly comprising small towns or villages, where the internet transmission signal is inadequate. There are some remote rural areas which are not even reached by radio broadcasting. Moreover, being in urban centers does not mean having access to broadband internet, because the service may be more unstable in the city outskirts. According to Lis (2020) and Yuge (2020), the National Telecommunications Agency is receiving a rising number of complaints about the lack of broadband internet provision in Brazil. Cardoso (2020) reports about the difficulty in accessing broadband internet in the outskirts of São Paulo, the largest urban center in the most economically developed region of the country, where, according to the State Data Analysis System Foundation (2020), more than 7,500,000 people have never had access to the Internet. Soprana (2020) states that there are more than 70 million Brazilians without internet access in Brazil. The situation with regard to internet access is even more aggravated in the North and Northeast regions 
of Brazil, where only $28.7 \%$ and $30 \%$ of the population, respectively, have access to the internet. Among blacks and mestizos in the country as a whole only 23.9\% have internet access (Brazilian Institute of Geography and Statistics, 2019). As the majority of the black population lives in poverty, black students represent a particularly vulnerable population in terms of access to quality internet service.

Even though internet access is unevenly available, the use of mobile phones has grown among socially disadvantaged Brazilians. The National Household Sample Survey indicated that $96 \%$ of Brazilian households owned at least one mobile phone in 2018. The ICT Report confirms that most Brazilians have access to an internet connection by using mobile phones for basic daily activities, but points out "[...] that important limitations persist for carrying out activities that demand greater connection capacity and data traffic" (Brazilian Institute of Geography and Statistics, 2019, p. 101). In general, the most used mobile phones are not equipped in terms of hardware and software to work with digital platforms or to support the large-volume downloads required for studies. In that sense, classes would have to be taught by using social media applications such as Instagram, Facebook, WhatsApp, which would ensure greater usability, but also impose much greater restrictions in terms of the resources that can be used. That means that internet access through a mobile phone may not be enough to support participation in online education.

It is not only the job, income, and digital limitations that threaten student retention in higher education during the pandemic. Students' autonomy, inadequate home environments to follow synchronous and/or asynchronous classes, and the difficulties in concentration that result from discontinuity, require cognitive adaptations to the teaching-learning process. Changes in working hours, the additional physical and emotional fatigue that affects those who are still working, and several mental health issues caused or exacerbated by social isolation, require physical and psychoemotional adaptations to mitigate the challenges of studying during the pandemic (Sahu, 2020). The discontinuity of class schedules, loss or extension of semesters in public HEIs, the impossibility of carrying out job and internship activities in public and private HEIs, and several other uncertainties caused by the pandemic have taken a heavy toll on students. The need to deal with illness, death, and social isolation has had severe psycho-emotional impacts on students who have seen their routines changed and/or had to assume family responsibilities even while grieving (Sahu, 2020; Vieira, 2020), consequently, that has brought sickness conditions to the students' mental health (Araújo et al., 2020; Son et al., 2020).

COVID-19 also interferes with secondary education in Brazil, which will have repercussions on the access to higher education. The Brazilian Association of Higher Education Administrators (2020c) pointed out that, for example, the delay in carrying out the National High School Examination (ENEM) may generate a "blackout" in the skilled labor in the future. The transition between school and the labor market has already been heavily impacted by the pandemic. ENEM, an important public policy governing access to higher education, was the object of heated political debate in this pandemic year. The Ministry of Education, contrary to the WHO guidelines, has kept the exam schedule in November 2020. Several groups opposed that decision, and mobilized the justice system to assess the adequacy of the schedule. Finally, the Ministry of Education agreed to postpone ENEM by 30-60 days (Anísio Teixeira National Institute of Studies and Educational Research, 2020).

Resistance to taking the exam has exposed the inequalities in terms of candidates' social vulnerability due to suspended classes and/or the digital exclusion exacerbated by the pandemic. Saboia (2020) revealed the reality of favela residents in Rio de Janeiro, who see their dream of 
access to higher education undermined by the lack of ability to follow synchronous or asynchronous online preparatory courses for the ENEM test. Illustrating the insensibility of the current Brazilian government towards social vulnerabilities and inequalities, the former Minister of Education Abraham Weintraub stated in an interview for CCN Brazil that ENEM does not have the mission to relieve social injustices, but merely select the best candidates. This is a surprising statement given that ENEM was created with the mission of reducing inequalities. He went on to mock the notion that some candidates lacked adequate internet access, claiming that they could not have registered for the exam if they did not have access to the internet (Mendonça, 2020).

The pandemic has caused considerable disruptions for students, parents, educators and higher education institutions in Brazil. A significant amount of students and their families have been affected by the loss of jobs, income and other opportunities that forced high numbers of students to interrupt their studies. Many students do not have access to the infrastructure and high quality internet that is required for distance education. Also the entry into higher education has been disrupted by the inability of many students to prepare for the ENEM test. The private HEIs, which are usually attended by wealthier students, have been better prepared to move their classes online, while the students from the poorest racialized groups have been the most affected.

\section{Conclusion}

The COVID-19 pandemic has exacerbated weaknesses and inequalities that threaten access and retention in Brazilian higher education. The instability of the labor market, loss of jobs, and latent uncertainties about the future of the labor market weaken the determination and ability of students to remain in higher education. Public HEIs especially lack adequate technological infrastructure to support the academic faculty in delivering courses online. Teachers often feel unprepared to handle technological resources, digital platforms, and virtual classrooms.

Access to higher education in Brazil has historically been limited to the privileged elite. Based on colonial legacies, societal inequalities in Brazil are reflected in its education system. Despite policy reforms, access to higher education in the country is still far from equitable. Access to public HEIs is limited because there are not enough places to accommodate all students who apply, while private HEIs restrict access through high tuition fees. Public policies for student funding exist, but they are volatile and threatened by cuts. The lack of purchasing power of technological resources and internet access, an essential element for the continuity of academic activities, add to the challenges.

All in all, the COVID-19 crisis has made the need to improve access to and retention in higher education for socially disadvantaged students more visible and urgent, also with a view to the postpandemic future. I would argue that the most important task is the universalization of higher education through the law, as already implemented for primary and lower secondary education in 1996. It is essential that public policies for the financing of private higher education are expanded by the state, allowing for lower tuition fees, and increased accessibility for socially disadvantaged students.

With most of the scenarios for the likely course of the pandemic in Brazil being pessimistic, it is vital that the state should be obliged to guarantee access to the internet as a civil right, and the use of the internet and ICT as a guarantee of continuity and retention in higher education. It is up to the state to develop mechanisms that sustainably boost the purchasing power for laptop, desktop, or tablet computers. It should also be the state's obligation to equip students in vulnerable situations with technological resources, by ensuring internet access to synchronous and/or hybrid classes in 
public HEIs. In private and public HEIs, the regulatory state must not only ensure the availability of courses of study, but also guarantee access for all students, including, if necessary, distributing SIM cards for internet access.

More research is needed about the impact of COVID-19 on higher education in Brazil from different perspectives. The right to higher education, whether in classroom or online mode, needs to become a greater part of popular political awareness, thereby exerting pressure on political leaders. That also implies a new conception of the role and responsibilities assumed by the government for education, as education has the potential to transform the lives of poor and excluded people. Most importantly, public policies need to consider the need for more expansion of public HEIs, and more opportunities for student financing in private HEIs.

\section{References}

Adnan, M., \& Anwar, K (2020). Online learning amid the COVID-19 pandemic: Student's perspectives. Journal of Pedagogical Sociology and Psychology, 2(1), 45-51. https://doi.org/10.33902/JPSP.2020261309

Ahlburg, D. A. (2020). Covid-19 and UK universities. The Political Quarterly, 91(3), 649-654. https://doi.org/10.1111/1467-923X.12867

Anísio Teixeira National Institute of Studies and Educational Research (2000a). Evolução do Ensino Superior - Graduação 1980-1998 [Evolution of Higher Education - Undergraduate Degree]. INEP. Retrieved from http://download.inep.gov.br/download/censo/1998/superior/evolucao_1980-1998.pdf.

Anísio Teixeira National Institute of Studies and Educational Research (2000b). Sinopse estatística da educação superior - Graduação - 1999 [Statistical synopsis of higher education Undergraduate Degree]. INEP. Retrieved from http://download.inep.gov.br/download/censo/1999/superior/miolo1_Sinopse_Superior99.pdf

Anísio Teixeira National Institute of Studies and Educational Research (2001). Sinopse estatística da educação superior - 2000 [Statistical synopsis of higher education]. INEP. Retrieved from http://download.inep.gov.br/download/censo/2000/Superior/sinopse_superior-2000.pdf

Anísio Teixeira National Institute of Studies and Educational Research (2012). Censo da Educação Superior 2010 - Resumo Técnico [Census of Higher Education 2010 - Technical Summary]. INEP. Retrieved from http://download.inep.gov.br/download/superior/censo/2010/resumo_tecnico_censo_educaca o_superior_2010.pdf

Anísio Teixeira National Institute of Studies and Educational Research (2019). Censo da Educação Superior 2018 - Divulgação dos Resultados [Census of Higher Education 2018 - Release of Results]. INEP. Retrieved from http://download.inep.gov.br/educacao_superior/censo_superior/documentos/2019/apresentac ao_censo_superior2018.pdf

Anísio Teixeira National Institute of Studies and Educational Research (2020). Nota de esclarecimento / ENEM 2020 [Clarification note] [dedicated webpage]. INEP. Retrieved from http://portal.inep.gov.br/artigo/-/asset_publisher/B4AQV9zFY7Bv/content/nota-deesclarecimen-7/21206

Anísio Teixeira National Institute of Studies and Educational Research (2021a). Sinopse estatística da educação básica - 2018 [Statistical synopsis of basic education]. INEP. Retrieved from https://www.gov.br/inep/pt-br/acesso-a-informacao/dados-abertos/sinopsesestatisticas/educacao-basica.

Anísio Teixeira National Institute of Studies and Educational Research (2021b). Sinopse estatística 
da educação superior - 2019 [Statistical synopsis of higher education]. INEP. Retrieved from 09 December 2021 from https://www.gov.br/inep/pt-br/acesso-a-informacao/dadosabertos/sinopses-estatisticas/educacao-superior-graduacao

Araújo, F. J. O., Lima, L. S. A., Cidade, P. I. M., Nobre, C. B., \& Rolim Neto, M. L. (2020). Impact of Sars-coV-2 and its reverberation in global higher education and mental health. Psychiatry Research, 288. http://dx.doi.org/10.1016/j.psychres.2020.112977

Aucejo, E. M., French, J., Araya, M. P. U., \& Zafar, B. (2020). The impact of COVID-19 on student experiences and expectations: Evidence from a survey. Journal of Public Economics, 191. https://dx.doi.org/10.1016\%2Fj.jpubeco.2020.104271

Badalotti, T. S., Toassi, R. F. C., \& Celeste, R. K. (2019). Facing the discriminatory phenomenon in adult population. Physis, 29(4). https://doi.org/10.1590/s0103-73312019290415

Barone, L. (2020). Educação Pública na pandemia: faltam estratégias para enfrentar situações como a COVID-19 [Public Education in the pandemic: strategies to address situations such as COVID-19 are lacking]. Gazeta do Povo. Retrieved from http://abed.org.br/arquivos/Sistema_de_ensino_publico_mostra_despreparo_para_lidar_com _coronavirus.pdf

Bezerra, A. C.V., Silva, C. E. M., Soares, F. R. G., \& Silva, J. A. M. (2020). Factors associated with people's behavior in social isolation during the COVID-19 pandemic. Ciênc. saúde coletiva, 25(Supl 1), 2411-2121. https://doi.org/10.1590/1413-81232020256.1.10792020

Brazilian Association of Higher Education Administrators (2020a). ABMES: inadimplência em maio cresce $75 \%$ e ensino a distância deve supercar ensino presencial em 2022 [ABMES: non-payment rate grows $75 \%$ in May and distance education expected to surpass face-toface education in 2022]. ABMES. Retrieved from

https://abmes.org.br/noticias/detalhe/3809/abmes-inadimplencia-em-maio-cresce-75-eensino-a-distancia-deve-superar-presencial-em-2022

Brazilian Association of Higher Education Administrators (2020b). ABMES: Pesquisa revela que $42 \%$ dos alunos podem abandoner faculdades privadas [ABMES: Survey reveals that $42 \%$ of students can drop out of private colleges]. ABMES. Retrieved from https://abmes.org.br/noticias/detalhe/3814/pesquisa-revela-que-42-dos-alunos-podemabandonar-faculdades-privadas

Brazilian Association of Higher Education Administrators (2020c). ABMES: Sem dinheiro, estudantes recorrem à justiça por redução de mensalidades em universidade [ABMES: Without money, students go to court for tuition reduction in universities]. ABMES. Retrieved from https://abmes.org.br/noticias/detalhe/3902/sem-dinheiro-estudantesrecorrem-a-justica-por-reducao-de-mensalidades-em-universidade

Brazilian Institute of Geography and Statistics (1950). Sinopse Preliminar do Censo Demográfico 1950 [Preliminary Synopsis of the Demographic Census]. IBGE. Retrieved from https://biblioteca.ibge.gov.br/visualizacao/periodicos/313/cd_1950.pdf

Brazilian Institute of Geography and Statistics (1970). Tabulações Avançadas do Censo Demográfico - Resultados Preliminares [Advanced Demographic Census Tabulations Preliminary Results]. IBGE. Retrieved from https://biblioteca.ibge.gov.br/visualizacao/livros/liv84447.pdf

Brazilian Institute of Geography and Statistics (2019). Síntese de indicadores sociais: uma análise das condições de vida da população Brasileira: 2019 [Synthesis of social indicators and analysis of the living conditions of the Brazilian population]. Rio de Janeiro: IBGE. Retrieved from https://biblioteca.ibge.gov.br/visualizacao/livros/liv101678.pdf Brazilian Institute of Geography and Statistics. (2020). PNAD COVID-19: Trabalho. IBGE. Retrieved from https://covid19.ibge.gov.br/pnad-covid/trabalho.php Burki, T. K. (2020). COVID-19: Consequences for higher education. The Lancet Oncology, 21(6), 
758. https://doi.org/10.1016/S1470-2045(20)30287-4

Cardoso, W. (2020). Periferia de São Paulo sofre com a falta de acesso à internet [Outskirts of São Paulo suffer from lack of internet access]. Folha de São Paulo. Retrieved 29 september 2020 from Periferia de São Paulo sofre com a falta de acesso à internet - 23/08/2020 - São Paulo Agora (uol.com.br)

Daniel, J. (2020). Education and the COVID-19 pandemic. Prospects, 49, 91-96, https://doi.org/10.1007/s11125-020-09464-3

DeHumerez D. C., \& Jankevicius, J. V. (2015). Evolução histórica do Ensino Superior no Brasil [Historical evolution of Higher Education in Brazil]. COFEN. Retrieved from

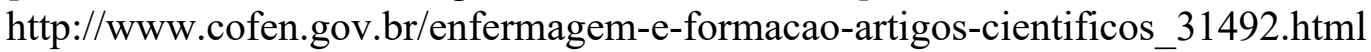

Federative Republic of Brazil (2012a). Lei No 12.711, de 29 de agosto de 2012. Dispõe sobre o ingresso nas universidades federais e nas instituições federais de ensino técnico de nível médio e dá outras providências. [Law No. 12,711 of August $29^{\text {th }}, 2012$ provides for admission to federal universities and federal high school technical institutions and provide other measures]. Retrieved from http://www.planalto.gov.br/ccivil_03/_ato20112014/2012/lei/112711.htm

Federative Republic of Brazil (2012b). Mensagem No 385, de 29 de agosto de 2012 [Message No. 385 of August, 29th 2012.]. Retrieved from http://www.planalto.gov.br/ccivil_03/_ato20112014/2012/Msg/VEP-385.htm

Federative Republic of Brazil (2012c). Lei $\mathrm{N}^{\mathrm{o}} 7.824$, de 11 de outubro de 2012. Regulamenta a Lei $\mathrm{N}^{\mathrm{o}}$ 12.711, de 29 de agosto de 2012, que dispõe sobre o ingresso nas universidades federais e nas instituições federais de ensino técnico de nível médio. [Law No. 7,824 of October $11^{\text {th }}$, 2012. Regulates Law No. 12,711 of August 29th, 2012 , which provides for admission to federal universities and federal high school technical education institutions. Retrieved from http://www.planalto.gov.br/ccivil_03/_ato2011-2014/2012/decreto/d7824.htm

Federative Republic of Brazil (2015). Lei $\mathrm{N}^{\mathrm{o}}$ 13.146, de 6 de julho de 2015. Institui a Lei Brasileira da Inclusão da Pessoa com Deficiência (Estatuto da Pessoa com Deficiência). [Law No. 13,146 of July $6^{\text {th }}, 2015$. Establishes the Brazilian Law of the Inclusion of Persons with Disabilities (Statute of Person with Disabilities]. Retrieved from http://www.planalto.gov.br/ccivil_03/_ato2015-2018/2015/lei/113146.htm

Federative Republic of Brazil (2016). Lei $\mathrm{N}^{\mathrm{0}} 13.409$, de 28 de dezembro de 2016. Altera a Lei $\mathrm{N}^{\mathrm{o}}$ 12.711 , de 29 de agosto de 2012, para dispor sobre a reserva de vagas para pessoas com deficiência nos cursos técnicos de nível médio e superior das instituições federais de ensino. [Law No. 13,409 of December 28 ${ }^{\text {th }}, 2016$. Amends Law No 12,711 of August 29 ${ }^{\text {th }}, 2012$ to provide for the reservation of vacancies for people with desabilities in technical courses of high and higher education of federal educational institutions]. Retrieved from http:/www.planalto.gov.br/ccivil_03/_ato2015-2018/2016/lei/113409.htm

Federative Republic of Brazil (2017a). LDB: Lei de Diretrizes e Bases da Educação Nacional [LDB: Law governing Guidelines and Bases of National Education]. Brasília: Federal Senate: Coordination of Technical Editions. Retrieved from https://www2.senado.leg.br/bdsf/bitstream/handle/id/529732/lei_de_diretrizes_e_bases_1ed. pdf

Federative Republic of Brazil (2017b). Decreto $N^{\circ}$ 9.034, de 20 de abril de 2017. Altera o Decreto $\mathrm{N}^{\mathrm{o}} 7.824$, de 11 de outubro de 2012, que regulamenta a Lei $\mathrm{N}^{\circ} 12.711$, de 29 de agosto de 2012, que dispõe sobre o ingresso nas universidades federais e nas instituições federais de ensino técnico de nível médio [Decree $\mathrm{N}^{\mathrm{o}} 9034$ of April 20 ${ }^{\text {th }}, 2017$. Amends Decree No 7,824 of October $11^{\text {th }}, 2012$, which regulates Law No. 12,711 of August 29 ${ }^{\text {th }}, 2012$, which provides for admission to federal universities and federal high-level technical education institutions.]. Retrieved from 
https://pesquisa.in.gov.br/imprensa/jsp/visualiza/index.jsp?jornal=1\&pagina $=1 \&$ data $=24 / 04 /$ 2017

Federative Republic of Brazil (2017c). Decreto No 9.057, de 25 de maio de 2017. Regulamenta o art. 80 da Lei n. 9.394, de 20 de dezembro de 1996, que estabelece as diretrizes e bases da educação nacional [Degree N 9057 of May 25, 2017. Regulates Art. 80 of Law No. 9304 from December $20^{\text {th }}, 1996$, which governs the guidelines and bases of national education]. Union Official Gazette. Resource document. Diário Oficial da União, May $3^{\text {rd }}$. Retrieved from

http://pesquisa.in.gov.br/imprensa/jsp/visualiza/index.jsp?data=26/05/2017\&jornal=1\&pagi na $=3 \&$ totalArquivos $=240$

Federative Republic of Brazil (2019). Portaria N $\mathrm{N}^{\mathrm{a}} 2.117$, de 6 de dezembro de 2019. Dispõe sobre a oferta de carga horária na modalidade de Ensino a Distância - EaD em cursos de graduação presenciais ofertados por Instituições de Educação Superior - IES pertencentes ao Sistema Federal de Ensino [Ordinance No. 2117 from December $6^{\text {th }}, 2019$ governing the provision of workload in the Distance Learning modality in face-to-face undergraduate programs offered by Higher Education Institutions of the Federal Education System]. Official Daily Union. Retrieved from http://www.in.gov.br/en/web/dou/-/portaria-n-2.117-de-6-de-dezembro-de2019-232670913

Federative Republic of Brazil (2020a). Portaria No 343, de 17 de março de 2020. Dispõe sobre a substituição das aulas presenciais por aulas em meios digitais enquanto durar a situação de pandemia do Novo Coronavírus - COVID-19 [Ordinance No 343 of March 17 $7^{\text {th }}, 2020$. Provides for the replacement of face-to-face classes by classes through digital media during the pandemic situation of the novel Coronavirus - COVID-19]. Union Official Gazette, 39. Retrieved from http://pesquisa.in.gov.br/imprensa/jsp/visualiza/index.jsp?data $=18 / 03 / 2020 \&$ jornal $=515 \& p a$ gina $=39$

Federative Republic of Brazil (2020b). Portaria No 1.122 de 19 de março de 2020. Define as prioridades, no âmbito do Ministério da Ciência, Tecnologia, Inovações e Comunicações (MCTIC), no que se refere a projetos de pesquisa, de desenvolvimento de tecnologias e inovações para o período 2020 a 2023 [Ordinance No. 1122 from March 19 ${ }^{\text {th }}, 2020$. Defines priorities within the scope of the Ministry of Science, Technology, Innovation and Communications (MCTIC) with regard to research projects, technology development, and innovations for the period from 2020 to 2023]. Union Official Gazette. 24 March. Retrieved from http://www.in.gov.br/en/web/dou/-/portaria-n-1.122-de-19-de-marco-de-2020249437397

Feres Júnior, J., Campos, L. A., Daflon, V. T., \& Venturini, A. C. (2018). O conceito de Ação Afirmativa. In J. Feres Júnior, L. A. Campos, V. T. Daflon, \& A. C. Venturini (Eds.), Ação afirmativa: conceito, história e debates [online] (pp. 13-26). Rio de Janeiro: EDUERJ. https://doi.org/10.7476/9786599036477

Furuno, F. (2020). Coronavírus: Brasil está preparado para o estudo remoto? [Coronavirus: Is Brazil ready for remote study?]. Desafios da Educação. Retrieved from https://desafiosdaeducacao.grupoa.com.br/coronavirus-Brazil-estudoremoto/?fbclid=IwAR0ZUOx5aWoUb3OxbwO2rSsdbcWH9ax_zLP9LeNBR536fG9TKgPf eL0NIHg

Gazeta do Povo (2019). Ministro da Educação diz que "Universidade para todos não existe" [Education Minister says "There is no University for All”]. Retrieved from https://www.gazetadopovo.com.br/educacao/ministro-da-educacao-diz-queuniversidadepara-todos-nao-existe-9cb1w24y18605jt0mllog2gnp/

Getúlio Vargas Foundation (2020). Pandemia já afeta trabalho de 53,5\% das famílias, aponta 
FGV/IBRE [Pandemic already affects jobs of 53.5\% of families according to FGV/IBRE].

Retrieved from https://portal.fgv.br/noticias/pandemia-ja-afeta-trabalho-535-familiasaponta-fgv-ibre

Internet Steering Committee in Brazil (2019). Pesquisa sobre o uso das tecnologias de informação e comunicação nos domicílios Brasileiros: TIC domicílios 2018 = Survey on the use of information and communication technologies in Brazilian households: ICT households 2018 [eletronic book]. São Paulo: Comitê Gestor da Internet no Brasil. Retrieved from https://www.cgi.br/media/docs/publicacoes/2/12225320191028tic_dom_2018_livro_eletronico.pdf

Kerres, M. (2020). Against all odds: Education in Germany coping with Covid-19. Postdigital Science and Education, 690-694. https://doi.org/10.1007/s42438-020-00130-7

Lis, L. (2020). Pandemia fez crescer em quase 32\% reclamações contra banda larga fixa, diz Anatel [Pandemic increased complaints against fixed broadband by almost 32\%, says Anatel]. G1. Retrieved from https://g1.globo.com/economia/noticia/2020/08/04/pandemia-fez-crescerem-quase-32percent-reclamacoes-contra-banda-larga-fixa-informa-anatel.ghtml

Mendonça, A. (2020). Weintraub-sobre-ENEM: 'Não é para atender injustiças sociais, é para selecionar os melhores' [Weintraub on ENEM: 'It's not designed to respond to social injustices, but it's to select the best]. Diário de Pernambuco. Retrieved from https://www.diariodepernambuco.com.br/noticia/Brazil/2020/05/weintraub-sobre-enem-naoe-para-atender-injusticas-sociais-e-para-s.html

Ministry of Education of Brazil (2018a). ProUni - Apresentação [ProUni Presentation] [dedicated webpage]. Ministry of Education. Retrieved from http://portal.mec.gov.br/index.php?option=com_content\&view=article\&id=205\&Itemid=29 8\&msg=1\&l=aW5kZXgucGhwP29wdGlvbj1jb21fY29udGVudCZ2aWV3PWJ1c2NhZ2Vy YWwmSXRlbWlkPTE2NCZwYXJhbXNbc2VhcmNoX3JlbGV2YW5jZV09UFJPVU5JJm Q9cyZwYXJhbXNbZGVdPSZwYXJhbXNbYXRIXT0mcGFyYW1zW2NhdGlkXT0mcGF yYW1zW3N1YXJjaF9tZXRob2RdPWFsbCZwYXJhbXNbb3JkXT1wcg==

Ministry of Education of Brazil (2018b). Novo ENEM [New ENEM] [dedicated webpage]. Ministry of Education. Retrieved from http://portal.mec.gov.br/component/content/article?id=13318\&Itemid=310

Ministry of Education of Brazil (2020a). Sistema de Seleção Unificada - SISU [Unified Selection System - SISU] [dedicated webpage]. Ministry of Education. Retrieved from https://sisu.mec.gov.br/\#/\#oquee

Ministry of Education of Brazil (2020b). Plano Nacional de Educação 2014-2024 [National Education Plan 2014-2024] [dedicated webpage]. Ministry of Education. Retrieved from http://pne.mec.gov.br/18-planos-subnacionais-de-educacao/543-plano-nacional-deeducacao-lei-n-13-005-2014

Moura, M. R. S., \& Tamboril, M. I. B (2018). “It is not free like that!!”: Quota act and challenges of difference. Psicol. Esc. Educ., 22(3), 593-602. http://dx.doi.org/10.1590/217535392018035604

Mustafa, N. (2020). Impact of the 2019-20 coronavirus pandemic on education. International Journal of Health Preference Research, 5(20), 31.

National Association of Private Universities (2021). Ordens judiciais que obrigaram desconto na mensalidade escolar são inconstitucionais, decide STF. [Court orders that forced discount on school fees are unconstitutional, decides STF]. Retrieved from https://anup.org.br/noticias/ordens-judiciais-que-obrigaram-desconto-na-mensalidadeescolar-sao-inconstitucionais-decide-stf/

National Education Development Fund (2017). FIES - Programa de Financiamento Estudantil [FIES - Student Financing Program]. FNDE. Retrieved from 
https://www.fnde.gov.br/financiamento/fundeb/area-para-gestores/dadosestatisticos/item/4752-histórico

National Union of Students (2016). Prounistas na rua contra os ataques de Temer e Mendonça à educação [Union supporters take to the street against Temer's and Mendonça's attack on education]. Retrieved from https://une.org.br/noticias/prounistas-na-rua-contra-os-ataquesde-temer-e-mendonca-a-educacao/.

Saboia, G. (2020). Sem internet, estudantes de favelas não conseguem se preparar para o ENEM [Without the internet, favela students can't get ready for ENEM]. Uol. Retrieved from https://educacao.uol.com.br/noticias/2020/04/28/sem-internet-estudantes-de-favelas-sofremcom-preparacao-online-para-enem.htm

Sahu, P. (2020). Closure of universities due to Coronavirus disease 2019 (COVID-19): Impact on education and mental health of students and academic staff. Cureus, 12(4). https://doi.org/10.7759/cureus.7541

Saldaña, P. (2019). Governo Bolsonaro reduz oferta do FIES a partir de 2021 e eleva desempenho mínimo do ENEM [Bolsonaro Government reduces FIES provision from 2021 on and raises minimum performance level in ENEM]. Estadão. Retrieved from https://www1.folha.uol.com.br/educacao/2019/12/governo-bolsonaro-reduz-oferta-do-fies-apartir-de-2021-e-eleva-desempenho-minimo-no-enem.shtml

Saviani, D. (2010). A expansão do ensino superior no Brasil: mudanças e continuidades [The expansion of the higher education in Brazil: changes and continuities]. PoíesisPedagógica, 8(2), 4-17. https://doi.org/10.5216/rpp.v8i2.14035

State Data Analysis System Foundation. (2020). São Paulo tem "ilha" de 7,5 mi de pessoas que nunca acessaram a internet [São Paulo has "island" of 7.5 million people who have never accessed the internet]. Seade. Retrieved from https://www.seade.gov.br/sao-paulo-tem-ilhade-75-mi-de-pessoas-que-nunca-acessaram-a-internet/

Segenreich, S. C. D. (2009). ProUni e UAB como estratégias de EAD na expansão do Ensino Superior [ProUni and UAB as strategies of Distance Learning in the expansion of higher education]. Pro-posições, 20(2). 205-222. http://dx.doi.org/10.1590/S010373072009000200013

Son, C., Hedge, S., Smith, A., Wang, X., \& Sasangolar, F. (2020). Effects of COVID-19 on college student's mental health in the United States: Interview survey study. Journal of Medical Internet Research, 22(9). https://dx.doi.org/10.2196\%2F21279

Soprana, P. (2020). 70 milhões de Brasileiros têm acesso precário a internet na pandemia [70 million Brazilians have precarious access to the internet in the pandemic]. Folha de São Paulo. Retrieved from https://www1.folha.uol.com.br/mercado/2020/05/cerca-de-70milhoes-no-Brazil-tem-acesso-precario-a-internet-na-pandemia.shtml

State of Ceará (2020). Lei $\mathrm{N}^{\circ} 17.208,11$ de maio de 2020. Dispõe sobre ações de proteção aos consumidores da rede privada de ensino durante o Plano de Contigência do novo Caronavírus (COVID-19) [Law No. 17208, from May 11 $1^{\text {th }}, 2020$ governing actions to protect consumers of the private school network during the Contigency Plan for the novel Caronavirus (COVID-19)]. Retrieved from http://imagens.seplag.ce.gov.br/PDF/20200511/do20200511p01.pdf.

Tomazinho, P. (2020). A aprendizagem não pode parar [Learning can not stop]. Retrieved from https://www.paulotomazinho.com.br/a-aprendizagem-nao-pode-parar.

UNESCO-International Institute for Higher Education in Latin America and the Caribbean (IESALC). (2020). COVID-19 and higher education - Today and tomorrow: Impacts, analysis, policy responses and recommendations. Resource document. United Nations Educational, Scientific and Cultural Organization. Retrieved from https://www.right-toeducation.org/es/node/1317 
Vieira, M. C. (2020). Na pandemia, jovens adiam o sonho do diploma universitário [In the pandemic, youngsters postpone their dream of a university degree]. Veja. Retrieved from https://veja.abril.com.br/educacao/na-pandemia-jovens-adiam-o-sonho-do-diplomauniversitario

Yuge, C. (2020). Reclamações sobre banda larga têm alta de 40\% durante a pandemia, diz Anatel [Complaints about broadband rise by $40 \%$ during the pandemic, says Anatel]. Canaltech. Retrieved from https://canaltech.com.br/internet/reclamacoes-sobre-banda-larga-tem-altade-40-durante-a-pandemia-diz-anatel-169374/

Zhu, X., \& Liu, J. (2020). Education in and after Covid-19: Immediate responses and long-term visions. Postdigital Science and Education, 2, 695-699. https://doi.org/10.1007/s42438-02000126-3 